\title{
On Further Study of Extracellular Accumulation of DNA by Hydrocarbon-utilizing Pseudomonas Species
}

\author{
Fusao Tomita, Toshihide Nakanishi and Takeo Suzuki \\ Tokyo Research Laboratory, Kyowa Hakko Kogyo Co., Ltd., Machida, Tokyo, Japan
}

Received July 30,1973

\begin{abstract}
Extracellular accumulation of high molecular weight DNA was further studied using Pseudomonas species. More efficient production was obtained by the use of glucose-grown seed culture and by controlling the broth-pH at around 6.0 for first $24 \mathrm{hr}$ and then around 8.0 during the fermentation. The maximum yield was 5 to $6 \mathrm{~g}$ per liter of the broth culture, which corresponded to 10 -fold of that reported in the previous work.

Purified DNA ( $4 \times 10^{6}$ daltons) was obtained successfully by applying an aqueous biphase system of dextran-polyethyleneglycol and dextranase.

Significant release of DNA occurred only with cell lysis of $n$-paraffin-grown bacteria. The primary cause of rapid lysis was explained by the exhaustion of cellular glucose pool. Relation of DNA accumulation to the effect of rhamnolipids on cell membrane was also investigated.
\end{abstract}

In our previous paper, ${ }^{1)}$ we reported that some hydrocarbon-utilizing Pseudomonad and Arthrobacter extracellularly accumulated high molecular weight DNA. The primary cause of DNA accumulation by Pseudomonad was explained by a rapid cell lysis occurred with the exhaustion of $n$-paraffin.

The present investigation was undertaken, on the one hand, to find the culture condition for the production of larger quantity of DNA and to isolate high molecular weight DNA more efficiently, on the other hand, to provide further evidence for the accumulation mechanism relating to the cell lysis.

This paper deals with the effect of carbon source in the seed culture and the $\mathrm{pH}$ of the culture medium, and with large scale-application of an aqueous biphase extraction of DNA. Relation of the cell lysis to internal glucose pool in $n$-paraffin-grown cells is also described.

\section{MATERIALS AND METHODS}

Microorganisms. Pseudomonas strains were from our laboratory stock. Among them, Pseudomonas fluorescens KY 4032 was studied extensively.

Culture methods. The composition of media for seed culture and fermentation was described previous- ly. ${ }^{11}$ The bacteria were grown in $250 \mathrm{ml}$ Erlenmeyer flasks or jar fermentors depending on the experimentations at $30^{\circ} \mathrm{C}$. All the experiments in flasks were carried out with shaking. The jar fermentor was operated under the same condition as described previously. ${ }^{11}$

Assays. Cell growth was estimated by absorbancy at $660 \mathrm{~nm}$ of appropriately diluted broth culture using a spectrophotometer. Assay of high molecular weight DNA was performed as follows; two times volume of ethanol was added to an aliquot of the broth supernatant and the resulted fibrous precipitates were subjected to the DNA assay of Dische ${ }^{2}$ after dissolving in a given amount of saline. Total amount of DNA was also determined by the same colorimetric method with $75 \%$ ethanol insoluble precipitates. RNA was assayed with $75 \%$ ethanol insoluble precipitates according to the method of Zamenhof. ${ }^{31}$ Dextran and glucose were determined respectively with Anthrone reagent ${ }^{\text {s/ }}$ and by the method of Somogyi. ${ }^{51}$

Chemicals. $n$-Paraffin mainly containing $\mathrm{C}-12$ to $\mathrm{C}-14$ fractions was obtained from the Nikko Petrochemical Co. (Japan). Dextran T-500 was the product of Pharmacia (Sweden). Polyethyleneglycol, "Carbowax 6000" was purchased from Union Carbide Chemical Co. (U.S.A.). Rhamnolipid was prepared by the method indicated previously. ${ }^{6 !}$ Dextranase was prepared from the broth supernatant of Aspergillus candidus by precipitation with ammonium sulfate $(0.8$ sat.) followed by acetone precipitation. The specific activity of the enzyme was found to be $2600 \mathrm{mg}$ 
of glucose liberated from the substrate $/ \mathrm{hr} / \mathrm{mg}$. All other chemical compounds were the best grade reagents.

\section{RESULTS AND DISCUSSION}

\section{Effect of carbon sources in the seed culture}

Since most of hydrocarbon-utilizing bacteria, belonging to Corynebacterium and its closely related group, utilize glucose poorly as the carbon source, sugar alcohols such as sorbitol have been generally used in the seed medium for their $n$-paraffin fermentation. Pseudomonad can utilize glucose effectively, thus sorbitol in the seed medium was replaced by glucose and its effect on accumulation of DNA was examined. As shown in Fig. 1, the growth rate in the fermentation medium was increased by the use of glucose-grown seed culture. In addition, the lysis of cells was also enhanced, thus it led to the accumulation of considerably great amount of DNA.

\section{Effect of $p H$ levels during the fermentation}

In preliminary experiments with flasks, we observed that the $\mathrm{pH}$ of the medium affected greatly on the growth rate and on the ac-

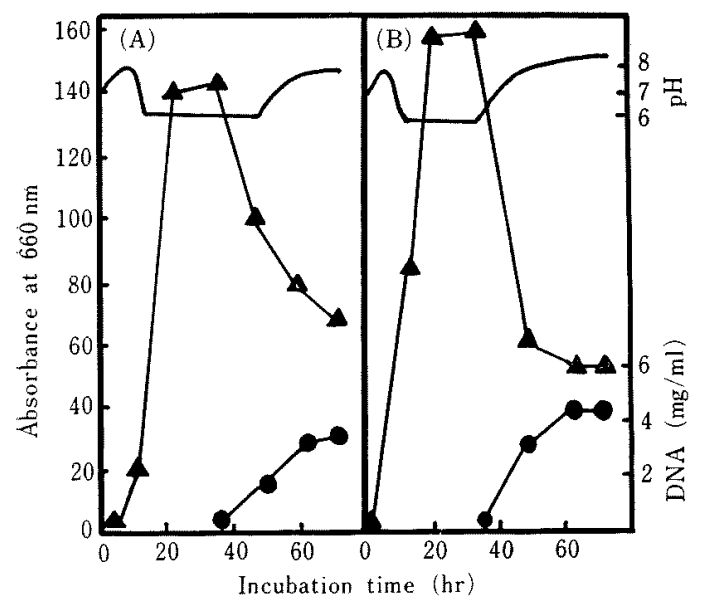

FIG. 1. Effect of Carbon Sources of Seed Medium on DNA Accumulation.

Incubation was carried out in 5 liter jar fermentors as described in the methods. The inoculum size for fermentation was $5 \%$ in volume.

(A) sorbitol-grown seed culture, (B) glucose-grown seed culture.

$\longrightarrow, \mathrm{pH} ; \boldsymbol{\Delta}-\boldsymbol{\Delta}$, growth; $-\longrightarrow$, DNA. cumulation of DNA. Therefore detailed examination was attempted about the effect of the $\mathrm{pH}$ on the fermentation. When the $\mathrm{pH}$ was controlled at around 6 for the first $24 \mathrm{hr}$ and then at around 8, the accumulation of high molecular weight DNA increased considerably and about $5 \mathrm{~g}$ per liter were obtained as the result of cell lysis. When the $\mathrm{pH}$ was controlled at around 7, little DNA was recovered as high molecular weight polymer as shown in Table $I$ and Fig. 2. However the total amount of DNA (low and high molecular weight) were not different significantly between the cultivations controlled at $\mathrm{pH} 7$ and $\mathrm{pH} 8$. From the above finding, the presence of active DNase was suspected in the broth culture controlled at $\mathrm{pH} 7$.

\section{Isolation of DNA from the broth culture}

Since a fairly large amount of the broth culture must be treated in this work, we chose the method of Rudin et al..$^{7)}$ because of mildness of the procedure. The method involves multistep liquid-liquid extraction with an aqueous polymer mixture of dextran and polyethyleneglycol. The original application of this method was made to the purifica-

\section{Table I. EfFect of pH Control} on DNA PRoduction

Seed cultures were performed with glucose medium. All measurements were made as indicated in the text.

\begin{tabular}{cclll}
\hline $\mathrm{pH}$ & $\begin{array}{c}\text { Time } \\
\text { (hr) }\end{array}$ & $\begin{array}{c}\text { High } \\
\text { molecular } \\
\text { weight DNA } \\
\mathrm{mg} / \mathrm{ml}\end{array}$ & $\begin{array}{c}\text { Total } \\
\text { DNA } \\
\mathrm{mg} / \mathrm{ml}\end{array}$ & $\begin{array}{c}\text { RNA } \\
\mathrm{mg} / \mathrm{ml}\end{array}$ \\
\hline \multirow{2}{*}{6} & 0 & 0 & 0.31 & 0.24 \\
& 48 & 0.02 & 0.65 & 0.26 \\
& 60 & 1.0 & 2.2 & 1.5 \\
& 72 & 3.0 & 4.1 & 2.2 \\
\hline 7 & 0 & 0 & 0.28 & 0.26 \\
& 48 & 0.09 & 0.64 & 0.17 \\
& 60 & 0 & 2.8 & 1.1 \\
& 72 & 0.02 & 4.6 & 1.4 \\
\hline $6 \rightarrow 8$ & 0 & 0 & 0.32 & 0.28 \\
& 48 & 0.6 & 1.3 & 0.41 \\
& 60 & 4.2 & 5.5 & 3.1 \\
& 72 & 3.8 & 4.8 & 2.5 \\
\hline
\end{tabular}




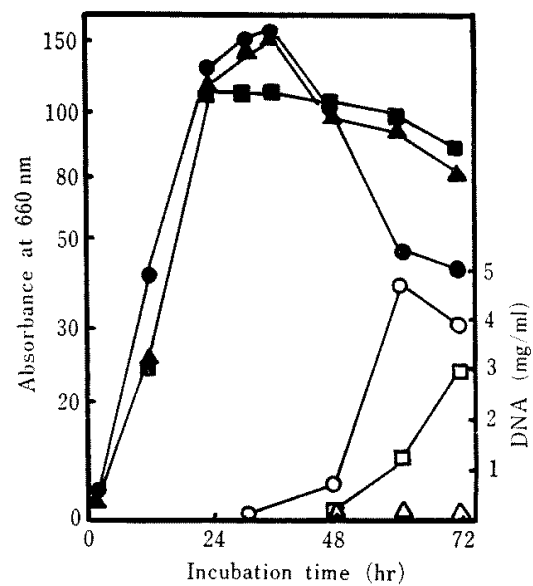

Fig. 2. Effect of $\mathrm{pH}$ on DNA Production.

Experiments were carried out in 5 liter jar fermentors. The open symbols indicate the amount of DNA accumulated and the closed symbols indicate the growth of bacterium $\left(\mathrm{A}_{660}\right)$.

-1-a, controlled at $\mathrm{pH} 6 ; \mathbf{\Delta - \Delta ,} \mathrm{pH} 7$; controlled at $\mathrm{pH} 6$ for the first $24 \mathrm{hr}$ and then at $\mathrm{pH} 8$ during fermentation.

tion of DNA from cell lysates of $E$. coli or $B$. subtilis in the definite composition of salts. In order to isolate high molecular weight DNA from the broth culture, this method was principally followed, although salts concentration was different from that as indicated by Rudin et al. Prior to the extraction, the supernatant fluid obtained by centrifugation of the broth culture was shaken with an equal volume of the mixture of chloroform and isoamylalcohol $(24: 1, \mathrm{v} / \mathrm{v})$. After centrifugation at $7000 \mathrm{rpm}$ for $15 \mathrm{~min}$, the upper layer containing nucleic acids was pipetted out. This procedure was repeated three times with lower layer. To the aqueous solution thus collected, $\mathrm{NaCl}$ ( $4 \mathrm{M}$ at the final concentration) was added to salt-out residual protein and to adjust the ionic strength for the subsequent procedure. The supernatant solution was subjected to the subsequent extraction with dextran-polyethyleneglycol $(0.2-7.3 \%)$. As shown in Fig. 3, protein and low molecular weight RNA were removed by repeating this extraction. High molecular weight DNA was obtained in upper layer of successive eight extraction "with dextran-polyethyleneglycol $(0.4-5.9 \%)$ containing $\mathrm{NaH}_{2} \mathrm{PO}_{4} \quad(5 \mathrm{~mm})$,

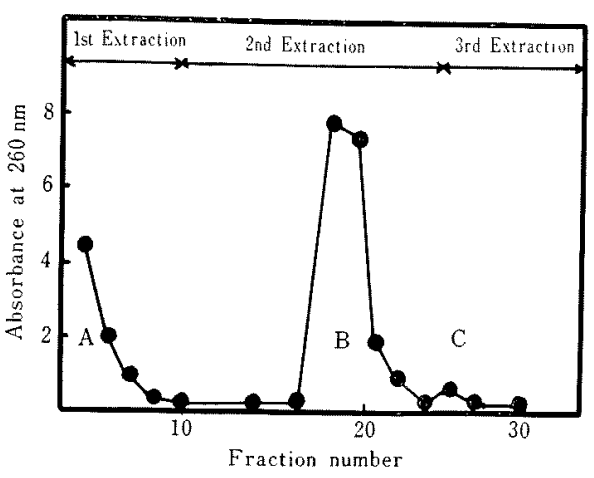

FIG. 3. Extraction Profile of Two Phase System.

Procedures for extraction were described in the text. $A$, protein and low molecular weight RNA; B, DNA; C, high molecular weight RNA.

$\mathrm{Na}_{2} \mathrm{HPO}_{4}(2 \mathrm{~mm})$ and sodium citrate $(1 \mathrm{~mm})$. Minor fraction was obtained separately from DNA fraction by further extraction with dextran-polyethyleneglycol $(0.4-5.9 \%)$ containing $\mathrm{Na}_{2} \mathrm{HPO}_{4}(5 \mathrm{~mm})$ and $\mathrm{Na}_{3} \mathrm{PO}_{4}(5 \mathrm{~mm})$ and characterized as high molecular weight DNA.

As mentioned above, the method of Rudin

Broth culture

| centrifuged

Supernatant fluid mixed with $\mathrm{CHCl}_{3}+$ isoamylalcohol
centrifuged repeated the above procedure three
times added $4 \mathrm{M} \mathrm{NaCl}$

Supernatant fluid

mixed with dextran $(6 \%)$, polyethyleneglycol $(12 \%)$ and $4 \mathrm{M} \mathrm{NaCl}$

Lower layer

mixed with dextran $(0.2 \%)$, polyethyleneglycol $(7.3 \%)$ and $4 \mathrm{M} \mathrm{NaCl}$

Lower layer

repeated the above procedure four times

mixed with dextran $(0.4 \%)$, polyethyleneglycol $(5.9 \%), 5 \mathrm{~mm} \mathrm{NaH} \mathrm{PO}_{4}, 5 \mathrm{~mm} \mathrm{Na} \mathrm{HPO}_{4}$ and 1 mM sodium citrate

Lower layer

| repeated the above procedure eight times

Upper layer (DNA fractions)

added 0.1 vol. polyethyleneglycol $(40 \%)$ and 0.05 vol. of $0.4 \mathrm{M} \mathrm{Na}_{2} \mathrm{HPO}_{4}$

Upper layer

I mixed with 1 vol. of $\mathrm{CHCl}_{3}$

Upper layer

l added dextranase, dialysed and deproteinized Supernatant fluid

I added ethanol

DNA (purified)

Final yield $13 \%$

FIG. 4. Isolation Procedure of DNA by Phase System. 


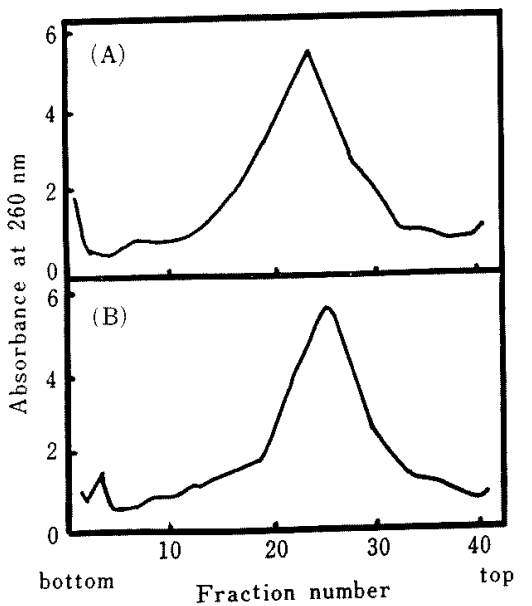

FIG. 5. Zone Sedimentation of DNA.

Samples were layered on the top of the gradient $(53 \mathrm{ml})$ of sucrose $(5$ to $20 \%)$ in SSC $(0.15 \mathrm{M} \mathrm{NaCl}+$ $0.015 \mathrm{~m}$ sodium citrate, $\mathrm{pH} 7.2$ ). After centrifugation, fractionation of the tube contents was carried out through a needle introduced in the bottom of the tube. Centrifugation was conducted with a Hitach RPS25-2 rotar at $20,000 \mathrm{rpm}$ for $20 \mathrm{hr}$.

(A) without dextranase, (B) with dextranase treatment.

et al. proved to be applicable for the broth culture without modification. Figure 4 presented a typical extraction flow for the large scale preparation. As shown in Fig. 4, DNA fraction thus obtained was mixed with 0.1 vol. of polyethyleneglycol $(40 \% \mathrm{w} / \mathrm{w})$ and $0.05 \mathrm{vol}$. of $\mathrm{Na}_{2} \mathrm{HPO}_{4}(0.4 \mathrm{M})$, and centrifuged at $3000 \mathrm{rpm}$ for $5 \mathrm{~min}$. Upper layer was extracted again with chloroform to remove concomitted polyethyleneglycol. Small amount of dextran contaminated in the aqueous layer thus obtained. Therefore dextranase treatment was employed in $0.2 \mathrm{M}$ citrate buffer $\left(\mathrm{pH} 5.0\right.$ ) for $30 \mathrm{~min}$ at $30^{\circ} \mathrm{C}$. Under this condition, 5 to $100 \mu \mathrm{g}$ of dextranase per $\mathrm{ml}$ was proved to be available without any degradation of DNA, by the observation of sedimentation pattern in sucrose density gradient. From the solution treated with dextranase, purified fibrous DNA was obtained by ethanol precipitation. Molecular weight of the isolat ed DNA was calculated to be $4 \times 10^{6}$ daltons from the result of zone sedimentation as shown in Fig. 5.
Some possible factors responsible for DNA accumulation

Rhamnolipids. In our previous papers ${ }^{6,8}$ it was reported that many strains of Psedomonas aeruginosa, when grown on $n$-paraffin as the sole source of carbon, produced a fairly large amounts of two sorts of rhamnolipids, either of which was made as an important factor for $n$-paraffin utilization by the bacteria. A possible role of rhamnolipids in $n$-paraffin utilization was realized in their activity as a surface active agent which is responsible for dispersing $n$-paraffin in the broth culture.

\section{Table II. Production of DNA} BY VARIous Pseudomonas

Incubation was carried out in $250 \mathrm{ml}$ flasks with shaking. All measurements were performed after 3 days of fermentation.

\begin{tabular}{|c|c|c|c|c|}
\hline \multicolumn{2}{|l|}{ Strain } & \multirow{2}{*}{$\frac{\mathrm{DNA}}{\mathrm{mg} / \mathrm{ml}}$} & \multirow{3}{*}{$\frac{\begin{array}{c}\text { Rhamno } \\
\text { lipids }\end{array}}{\begin{array}{c}\mathrm{mg} / \mathrm{ml} \\
0\end{array}}$} & \multirow{3}{*}{$\begin{array}{r}\text { Growth } \\
+\end{array}$} \\
\hline & & & & \\
\hline P. fluorescens & KY3965 & 0.5 & & \\
\hline & KY3974 & 0.6 & 0 & - \\
\hline & KY3975 & 1.3 & 1.5 & + \\
\hline & KY4032 & 3.1 & 5.7 & $+t$ \\
\hline & KY4033 & 0.5 & 0 & + \\
\hline P. syncyanea & KY4018 & 0.5 & 0 & \pm \\
\hline P. boreopolis & KY3967 & 0.4 & 0 & \pm \\
\hline P. chlorophis & KY4000 & 0.6 & 0 & + \\
\hline$P$. convexea & KY4014 & 0.4 & 0 & + \\
\hline P. cruciviae & KY3960 & 0.2 & 0 & + \\
\hline P. dacunhae & KY3952 & 0.4 & 0 & + \\
\hline$P$. fairmontensia & $\mathrm{KY} 4022$ & 0.2 & 0 & - \\
\hline$P$. marginalis & KY4013 & 0.3 & 0 & \pm \\
\hline P. melanogenum & KY3986 & 0.6 & 0 & \pm \\
\hline P. oleovorans & KY3981 & 0.2 & 0 & - \\
\hline P. polycolor & KY4015 & 2.1 & 5.2 & $++t$ \\
\hline P. robescens & KY3993 & 0.5 & 0 & + \\
\hline P. aeruginosa & KY3951 & 0.4 & 0 & \pm \\
\hline & KY3955 & 2.8 & 6.5 & $+t+$ \\
\hline & KY3976 & 0.3 & 0 & $\frac{1}{ \pm}$ \\
\hline & KY3977 & 1.2 & 0.8 & + \\
\hline & KY3996 & 3.0 & 5.9 & + \\
\hline & KY3997 & 2.0 & 0.8 & + \\
\hline & KY 4020 & 1.5 & 0.8 & + \\
\hline & KY4025 & 3.5 & 6.3 & $+t+$ \\
\hline & KY4027 & 3.8 & 3.2 & $t$ \\
\hline & KY4276 & 3.0 & 0.9 & + \\
\hline & KY8508 & 3.1 & 3.4 & ++ \\
\hline & KY8509 & 3.7 & 4.5 & ++ \\
\hline & KY8520 & 3.6 & 10.0 & + \\
\hline
\end{tabular}


However it was obscure how these lipids functioned on the cell surface when $n$-paraffin was exhausted at the end of the incubation even though they functioned as a growth stimulator during the growing phase. Considering that a primary cause of DNA release was the cell lysis which occurred with the exhaustion of $n$-paraffin, if rhamnolipid played also a part in the cell lysis of $n$-paraffin-grown cells, some correlations must be found between DNA accumulation and rhamnolipids. On the basis of the above assumption, various Pseudomonas species were compared of their growth on $n$-paraffin and productions of rhamnolipids and DNA. As summarized in Table II, almost all strains capable of producing rhamnolipids accumulated a fairly large amount of DNA. These results suggest a correlation of DNA accumulation and production of rhamnolipids.

In order to provide further evidence for the role of rhamnolipids in DNA release, the function of rhamnolipids as a surface activating agent was examined using spheroplasts. Spheroplasts of Pseudomonas fuorescens KY 4032 was prepared by lysozyme-EDTA method $^{9)}$ : bacterial cells grown on glucose or n-paraffin were collected respectively by centrifugation. Each preparation was then suspended (O.D. $\left.{ }_{660}=4.0\right)$ in Tris-buffer $(10 \mathrm{~mm}$, $\mathrm{pH} 7.4$ ) containing $4 \mathrm{~mm}$ EDTA, $0.5 \mathrm{~m}$ sucrose and lysozyme $(0.2 \mathrm{mg} / \mathrm{ml})$ and incubated at $30^{\circ} \mathrm{C}$ for $15 \mathrm{~min}$. The cells of both cultures proved microscopically to be converted to spheroplasts to the same extent. Spheroplasts thus obtained were used for subsequent experiments. To the surfactants dissolved in Tris-buffer (10 mM, pH 7.4) containing $0.5 \mathrm{M}$ sucrose, one eighth volume of spheroplasts suspension was added and the mixture was followed by the measurement of optical density at $660 \mathrm{~nm}$ by a spectrophotometer. As shown in Fig. 6, the rhamnolipid (2-O- $\alpha-\mathrm{L}-$ rhamnopyranosyl- $\alpha$ - L -rhamnosyl- $\beta$ - hydroxydecanoyl- $\beta$-hydroxydecanoate, $\mathrm{R}-1$ ) bursted the spheroplasts of glucose-grown cells at the concentration of $50 \mu \mathrm{g} / \mathrm{ml}$ which was far less amount compared with Tween 20 or

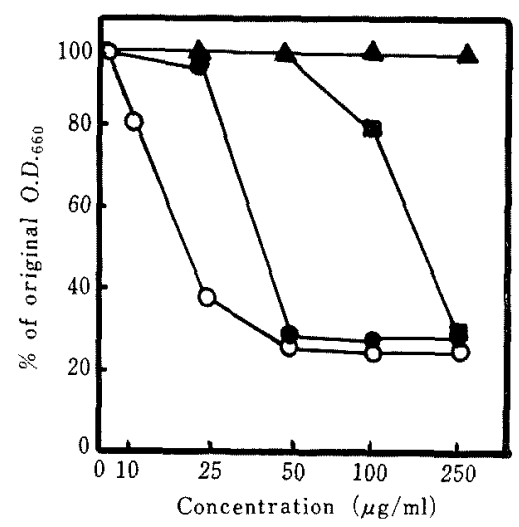

FIG. 6. Bursting of Spheroplasts by Rhamnolipid, R-1.

Spheroplasts were prepared from glucose-grown cells except those shown in open circles, which were prepared from $n$-paraffin-grown cells.

$\Delta-\mathbf{\Delta}$, Tween $20 ; \mathbf{v}-\mathbf{n}$, SDS; $-\bullet, 0-0, \mathrm{R}-1$.

sodium dodecyl sulfate. Comparing with spheroplasts prepared from hydrocarbongrown cells, there was a little difference in the susceptibility of those from glucose-grown cells towards the rhamnolipid (Fig. 6). As shown previously, $\left.{ }^{6}\right)$ either lysis or release of DNA was not observed in the glucose-medium even though $0.7 \mathrm{mg} / \mathrm{ml}$ of rhamnolipids were present. Thus it is difficult to explain the distinct difference in DNA production between glucose- and hydrocarbon-medium, from the difference in the susceptibility of spheroplasts towards rhamnolipids.

Subsequently the susceptibility of intact cells

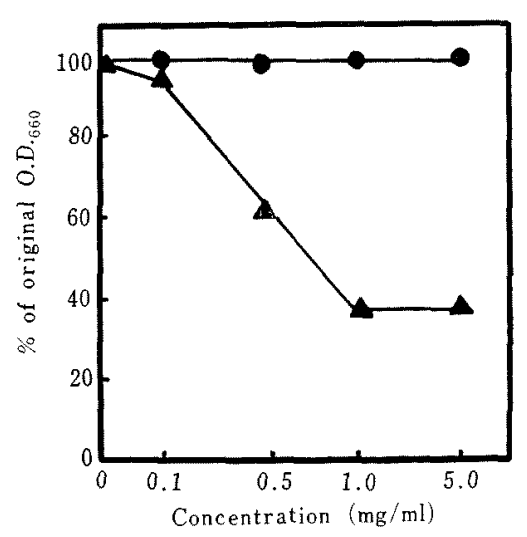

FIG. 7. Effect of Phamnolipid, R-1 to Intact cells. $\longrightarrow$ - R-1; $\wedge-\Delta$, SDS. 
towards R-1 was also examined. Glucose or hydrocarbon-grown cells were respectively collected by centrifugation and washed once with Tris-buffer (10 mM, pH 7.4). Washed cells suspended in the same buffer were contacted with $\mathrm{R}-1$. As shown in Fig. 7, incubation for $30 \mathrm{~min}$ at $30^{\circ} \mathrm{C}$ did not cause the bursting of cells even at the concentration of $5 \mathrm{mg}$ of $\mathrm{R}-1$ per $\mathrm{ml}$, which corresponded to five fold amount produced in the glucose medium. ${ }^{6)}$ In other experiment, R-1 (1.0 to $10 \mathrm{mg} / \mathrm{ml}$ ) was added to cells incubated overnight in glucose medium, but it did not also result in detectable lysis even by longer incubation. Accordingly it seems likely that rhamnolipids play only a minor role in lysis of cells and release of DNA, although the triggering action of rhamnolipids in autolysis was not resolved yet.

Glucose. We have shown in the previous paper $^{11}$ that Pseudomonad cells grown on glucose were resistant to lysis and did not release DNA. Therefore effect of glucose was examined again. Comparing with $n$ paraffin medium, glucose medium gave a less growth and no release of DNA (Fig. 8). When the concentration of glucose was reduced to $2.5 \%$, it resulted in the release of DNA associating with cell lysis after glucose was

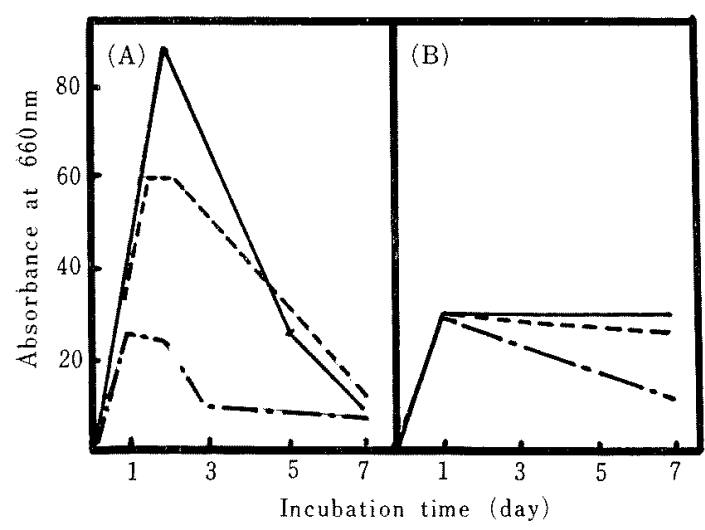

FIG. 8. Effect of Concentrations of $n$-Paraffin and Glucose on DNA Accumulation.

Incubation was carried out in $250 \mathrm{ml}$ flasks with shaking at $30^{\circ} \mathrm{C}$.

(A) $n$-paraffin, (B) glucose.

$\longrightarrow, 10 \% ;----, 5 \% ;-\cdots \cdot-, 2.5 \%$.
Table III. Effect of Carbon Sources oN DNA PRODUCTION

Incubation was carried out in $250 \mathrm{ml}$ flasks with shaking for 3 days. Carbon sources were added at the concentration indicated in the Table.

\begin{tabular}{|c|c|c|c|}
\hline \multirow[b]{2}{*}{ Carbon source } & \multicolumn{3}{|c|}{ DNA produced $(\mathrm{mg} / \mathrm{ml})$} \\
\hline & $2.5 \%$ & $5.0 \%$ & $10 \%$ \\
\hline n-Paraffin & 1.06 & 2.24 & 2.74 \\
\hline Glucose & 1.02 & 0.76 & 0.66 \\
\hline Sucrose & 1.18 & 1.17 & 1.26 \\
\hline None & 1.18 & - & - \\
\hline
\end{tabular}

consumed completely (Table III). The above finding suggests that starvation of the carbon source could be the primary cause of cell lysis.

Other possible factors. Although it is likely that the exhaustion of glucose from cellular pool was the primary cause of the cell lysis, the factor responsible directly for the lysis may remain to be found. In attempt to find it, the examination was focussed on the broth culture of hydrocarbon medium. The suppernatant fluid obtained from the broth culture after $48 \mathrm{hr}$ incubation was passed through a membrane filter (Millipore filter, pore size $0.3 \mu$ ) to remove living cells and used as the conditioned medium for subsequent experiments. Glucose-grown cells harvested at $48 \mathrm{hr}$ of incubation were incubated further in the conditioned medium supplemented with glucose or R-1. As indicated in Fig. 9, cells grew well in the conditioned medium without any supplement and lysed rapidly. Growth was stimulated extensively with supplementation of glucose, which was distinct from the observation in Fig. 8 where no lysis of cells were observed. This might indicate that the conditioned medium contained a factor stimulating growth. Residual glucose in the media was measured and found that in the conditioned medium glucose was almost completely consumed (Table IV). The above results suggested that exhaustion of carbon source might be the primary cause of rapid lysis. The presence of a factor stimulating autolysis was not plausible because cell lysis was not observed immediately after change of the medium. 
Table IV. Residual Glucose after Exchange of the Media

Incubation was carried out for 3 days after exchange of the media.

\begin{tabular}{|c|c|c|}
\hline \multirow[b]{2}{*}{ Additives } & \multicolumn{2}{|c|}{ Residual glucose $(\mathrm{mg} / \mathrm{ml})$} \\
\hline & $\begin{array}{l}\text { Conditioned } \\
\text { medium }\end{array}$ & $\begin{array}{l}\text { Fresh } \\
\text { medium }\end{array}$ \\
\hline None & 1.0 & 0.3 \\
\hline Glucose $5 \%$ & 0.9 & 2.2 \\
\hline $\begin{array}{l}\text { Rhamnolipid, } \\
\text { R-1 } 5 \mathrm{mg} / \mathrm{ml}\end{array}$ & 0.8 & 0.6 \\
\hline $\begin{array}{l}\text { Glucose } \\
5 \%+R-15 \mathrm{mg} / \mathrm{ml}\end{array}$ & 0.9 & 2.0 \\
\hline
\end{tabular}

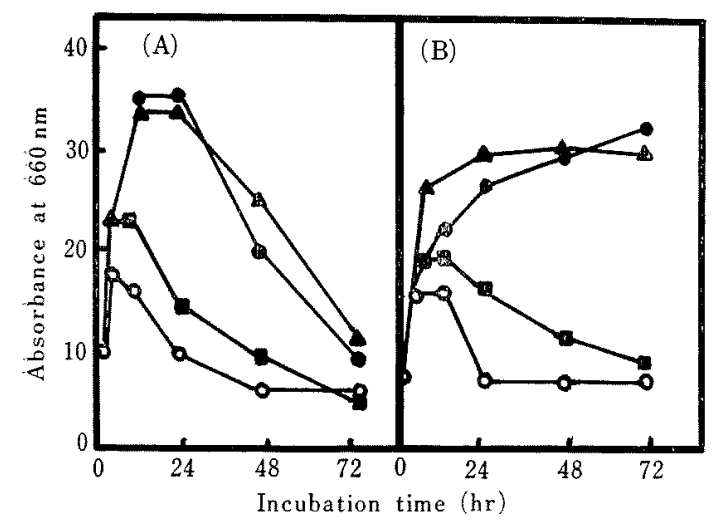

FIG. 9. Lysis of Cells in Conditioned or Fresh Medium. Experimental procedures were described in the text.

(A) conditioned medium, (B) fresh medium.

$\mathrm{O}-\mathrm{O}$, none; - - , glucose, $5 \%$;

- $\mathbf{a}$, rhamnolipid, $\mathrm{R}-1,5 \mathrm{mg} / \mathrm{ml}$;

$\Delta-\mathbf{\Lambda}$, glucose, $5 \%$ plus rhamnolipid, $5 \mathrm{mg} / \mathrm{ml}$.

Thus the rapid lysis in hydrocarbon-medium might be explained as follows; the intracellular pool of glucose, steadily synthesized from hydrocarbon, reduced rapidly after the substrate was exhausted and it consequently led to the cell lysis.

It has been shown that phospholipase $\mathrm{C}$ production parallels with the production of rhamnolipid $^{10)}$ and that phospholipase $\mathrm{C}$ might cause the triggering of lysis in Bacillus subtilis. ${ }^{11)}$ In our case also phospholipases might cause the triggering action after exhaustion of carbon sources in cellular pool. The investigation from the aspects of enzymic action are in progress in our laboratory.

\section{REFERENCES}

1) F. Tomita and T. Suzuki, Agr. Biol. Chem., 36, 133 (1972).

2) Z. Dische, Mikrochemie, 8, 4 (1930). Cited by Chargaff and Davidson, "The Nucleic Acid," Vol. 1, 1955, p. 287.

3) "Methods in Enzymology," Vol. III, ed. by S. P. Colowick and N. O. Kaplan, Academic Press Inc., New York, N.Y., 1957, p. 696.

4) T. A. Scott, Jr. and E. H. Melvin, Anal. Chem., 25, 1656 (1953).

5) M. Somogyi, J. Biol. Chem., 160, 61 (1945).

6) S. Itoh, H. Honda, F. Tomita and T. Suzuki, J. Antibiotics, 24, 855 (1971).

7) L. Rudin and P. A. Albertsson, Biochim. Biophys. Acta, 134, 37 (1967).

8) S. Itoh and T. Suzuki, Agr. Biol. Chem., 36, 2233 (1972).

9) H. C. Neu and L. A. Heppel, J. Biol. Chem., 239, 3893 (1964).

10) S. Kurioka and P. V. Liu, J. Bacteriol., 93, 670 (1967).

11) Y. Koga and I. Kusaka, Europ. J. Biochem., 16, 407 (1970). 